\title{
Pseudomonas panipatensis sp. nov., isolated from an oil-contaminated site
}

\author{
Sanjay Kumar Gupta, Rekha Kumari, Om Prakash and Rup Lal \\ Molecular Biology Laboratory, Department of Zoology, University of Delhi, Delhi 110007, India
}

Correspondence

Rup Lal

duzdel@vsnl.com

\begin{abstract}
A Gram-negative, motile, rod-shaped, non-sporulating, aerobic bacterial strain $\left(E s p-1^{\top}\right)$ was isolated from oil-contaminated soil of Panipat Oil Refinery, India, and its taxonomic position was determined using a polyphasic approach. Strain Esp- $1^{\top}$ grew in the presence of $2 \% \mathrm{NaCl}$ at $30{ }^{\circ} \mathrm{C}$ and was characterized chemotaxonomically by having $\mathrm{C}_{16: 0}$ as the major fatty acid followed by $\mathrm{C}_{17: 0}$ cyclo and $\mathrm{C}_{18: 1} \omega 7 \mathrm{c}$. Phylogenetic analysis based on 16S rRNA gene sequences showed that strain Esp- $1^{\top}$ formed a cluster together with Pseudomonas knackmussii DSM $6978^{\top}$ (98.9\% sequence similarity), Pseudomonas delhiensis MTCC $7601^{\top}$ (98.5\%), Pseudomonas nitroreducens DSM $14399^{\top}$ (98.5\%), Pseudomonas citronellolis DSM $50332^{\top}$ (98.7\%), Pseudomonas multiresinivorans ATCC $700690^{\top}(98.9 \%)$ and Pseudomonas jinjuensis DSM $16612^{\top}$ (97.8\%). DNA-DNA hybridization values of strain Esp-1 ${ }^{\top}$ with $P$. knackmussii DSM 6978 ${ }^{\top}, P$. delhiensis MTCC $7601^{\top}, P$. jinjuensis DSM $16612^{\top}, P$. citronellolis DSM $50332^{\top}, P$. multiresinivorans ATCC $700690^{\top}$ and $P$. nitroreducens DSM $14399^{\top}$ were 32.9, 30.2, 20.6, 23.4, 23.4 and 20.0\%, respectively. Low levels of DNA-DNA hybridization and phenotypic and chemotaxonomic results are sufficient to delineate strain Esp- $1^{\top}$ from other closely related species of Pseudomonas. Phenotypic and chemotaxonomic data confirm that strain Esp $-1^{\top}$ represents a novel species, for which the name Pseudomonas panipatensis sp. nov. is proposed. The type strain of Pseudomonas panipatensis sp. nov. is Esp $-1^{\top}$ (=MTCC $8990^{\top}=$ CCM $7469^{\top}$ ).
\end{abstract}

The genus Pseudomonas is an extremely heterogeneous group that has been reclassified several times on the basis of phenotypic features (Sneath et al., 1981), DNA-DNA hybridization (Palleroni, 1984), 16S rRNA gene sequence similarity (Anzai et al., 2000) and chemotaxonomic data (Oyaizu \& Komagata, 1983; Vancanneyt et al., 1996). Its members grouped previously into the $\alpha, \beta$ and $\gamma$ subclasses of the proteobacteria (Palleroni, 1984), but are now restricted to the $\gamma$ subclass, with Pseudomonas aeruginosa as the type species; members of the $\alpha$ and $\beta$ subclasses have been transferred to other genera (Kersters et al., 1996; Anzai et al., 2000).

Members of the genus Pseudomonas are ubiquitous in nature due to their metabolic versatility (Palleroni, 1993; Elkin \& Geddes, 2003; López-Romalde et al., 2003; Levitski-Heikkila \& Ullian, 2005). A number of pseudomonads are known to utilize a variety of xenobiotics as

\section{Abbreviation: TEM, transmission electron microscope.}

The GenBank/EMBL/DDBJ accession number for the $16 \mathrm{~S}$ rRNA gene sequence of Pseudomonas panipatensis Esp $-1^{\top}\left(=\right.$ MTCC $8990^{\top}=\mathrm{CCM}$ $7469^{\top}$ ) is EF424401.

DNA-DNA hybridization data for strain Esp $-1^{\top}$ and related species are available with the online version of this paper. sources of carbon and energy (Kiyohara et al., 1992; Johnsen et al., 1996; Stolz et al., 2007) and are thus exploited for the bioremediation of such compounds (O’Mahony et al., 2006; Onaca et al., 2007). Owing to their success in the bioremediation of soils with oily sludge (Lal \& Khanna, 1996; Mishra et al., 1999, 2001; Whyte et al., 2001), there have been quite a large number of attempts to isolate Pseudomonas from such sites (Bhattacharya et al., 2003; Prakash et al., 2007a).

In an ongoing study, a bacterial strain $\left(\mathrm{Esp}-1^{\mathrm{T}}\right)$ was isolated from an oil refinery (Panipat, India) that degrades citronellol (an isoprenoid and a component of oily sludge). Taxonomic studies based on 16S rRNA gene sequence analysis, morphological and physiological analysis, DNADNA relatedness and fatty acid patterns indicate that strain Esp- $1^{\mathrm{T}}$ represents a novel species of the genus Pseudomonas, for which the name Pseudomonas panipatensis sp. nov is proposed.

Soil samples collected from Panipat Oil Refinery were used to isolate bacterial strains. Strain Esp- $1^{\mathrm{T}}$ was isolated by a serial dilution plating method on Luria-Bertani (LB) agar ( $1.0 \%$ tryptone, $0.5 \%$ yeast extract, $0.5 \% \mathrm{NaCl}, 0.1 \%$ glucose) at $30{ }^{\circ} \mathrm{C}$. Cell morphology was examined after $72 \mathrm{~h}$ incubation at $30{ }^{\circ} \mathrm{C}$ by light microscopy (Motic B1 
series). The presence of flagella was determined with a transmission electron microscope (TEM) using cells from exponentially growing cultures. Cells were negatively stained with $0.5 \%$ uranyl acetate on copper grids and, after air drying, the grids were examined with a TEM (Morgagni 269D). Motility of the organism was studied by the hanging drop method as well as in motility agar (Farmer, 1999). Gram staining and spore staining were done using a Himedia kit. Growth at various temperatures, $\mathrm{pH}$ values and salt $(\mathrm{NaCl})$ concentrations was investigated in LB broth. Catalase activity was confirmed by adding $3 \%$ $(\mathrm{v} / \mathrm{v})$ hydrogen peroxide solution to colonies grown on LB agar. Cytochrome oxidase activity was determined by Kovac's reagent. Citronellol degradation, nitrate reduction, urease activity, and hydrolysis of starch, aesculin, hypoxanthine, xanthine, casein, gelatin, and Tweens 20 and 80 were determined as described by Prakash et al. (2007a). Degradation of phenanthrene, anthracene and naphthalene was determined according to the protocol described by Kiyohara et al. (1982). Acid production from carbohydrates was determined as described previously by Gordon et al. (1974). Antibiotic sensitivity tests were performed on Mueller-Hinton II medium using a readymade Sensi-Disc (Himedia) with various amounts of antibiotics. Other physiological tests were performed as described by Collins et al. (1989) and Stanier et al. (1966). Type strains were obtained from the DSMZ, Braunschweig, Germany, and used for comparative studies.

Fatty acid methyl ester analysis was carried out at the Institute of Microbial Technology, Chandigarh, India, as follows. Two to four loops of culture were scraped from a Petri dish and subjected to saponification, methylation and extraction using the methods of Miller (1982) and Kuykendall et al. (1988). Fatty acid methyl ester mixtures were separated using the Sherlock Microbial Identification system (MIDI) consisting of GC (Agilent 68900) and a flame ionization detector. Identification and comparisons were made using the Aerobe (TBSA50, version 5) database of the Sherlock Microbial Identification system. Genomic DNA extraction was performed as described by Pal et al. (2005).

Strain Esp- $1^{\mathrm{T}}$ was a Gram-negative, non-sporulating, rodshaped $(1.0-1.2 \times 2.8-3.5 \mu \mathrm{m})$ bacterium. It possessed a single polar flagellum (Fig. 1). Colonies were muddy-white,

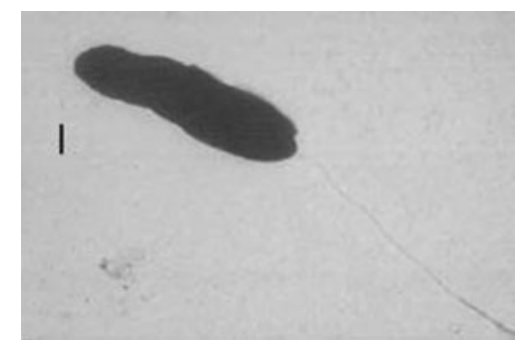

Fig. 1. TEM of negatively stained cells of strain Esp-1 $1^{\top}$ showing the presence of a single polar flagellum. Bar, $0.5 \mu \mathrm{m}$. smooth and circular in appearance. Citronellol degradation, nitrate reduction, and catalase and oxidase tests gave positive results. Xanthine, Tween 20, starch and gelatin were not hydrolysed, whereas hypoxanthine and Tween 80 were hydrolysed. Strain Esp $-1^{\mathrm{T}}$ was sensitive to oxytetracycline $(30 \mu \mathrm{g})$, tetracycline $(30 \mu \mathrm{g})$, kanamycin $(30 \mu \mathrm{g})$, gentamicin $(10 \mu \mathrm{g})$, neomycin $(30 \mu \mathrm{g})$ and chloramphenicol $(30 \mu \mathrm{g})$, but resistant to streptomycin $(10 \mu \mathrm{g})$, novobiocin $(30 \mu \mathrm{g})$, penicillin $\mathrm{G}(10 \mu \mathrm{g})$ and erythromycin $(15 \mu \mathrm{g})$. Strain Esp- $1^{\mathrm{T}}$ did not produce a clear zone when cultured on LB agar or minimal salt agar plates containing phenanthrene, anthracene or naphthalene. Phenotypic characteristics of strain Esp- $1^{\mathrm{T}}$ were compared with those of six closely related species of Pseudomonas (Table 1). Strain Esp $-1^{\mathrm{T}}$ showed remarkable differences from the closely related strain Pseudomonas knackmussii DSM $6978^{\mathrm{T}}$ with respect to colony colour, citronellol degradation, growth in $3 \% \mathrm{NaCl}(\mathrm{w} / \mathrm{v})$, nitrate reduction, hydrolysis of Tween 80 and hypoxanthine, production of urease, assimilation of D-glucose, D-fructose, liquid paraffin, heptane, L-histidine, L-serine, $\alpha$-naphthol, trehalose, sorbitol and acetate, and acid production from maltose and Dfructose. Phenotypic characteristics are important in delineating newly isolated strains from existing species (Stackebrandt et al., 2002). Hence, marked phenotypic differences between strain Esp- $1^{\mathrm{T}}$ and $P$. knackmussii enable them to be differentiated. Other phenotypic properties of strain Esp- $1^{\mathrm{T}}$ are given in the species description.

Analysis of the 16S rRNA gene sequence was carried out using a single colony from an overnight grown culture of the bacterium. This colony was picked up with a sterile tip, boiled in deionized water and centrifuged at $10000 \mathrm{~g}$ for $10 \mathrm{~min}$. The supernatant was diluted 10 -fold and used for PCR amplification. PCR amplification was carried out with Robocycler 96 (Stratagene) using a universal primer set corresponding to positions $27 \mathrm{~F}$ (16S forward primer; $5^{\prime}$ AGAGTTTGATCCTGGCTCAG-3') and 1492R (16S reverse primer; 5'-TACGGTTACCTTGTTACGACTT-3') of Escherichia coli (Prakash et al., 2007b). The PCR product $(1.5 \mathrm{~kb})$ was purified using a Qiagen kit according to the manufacturer's instructions and run on a 3100-Avant Genetic Analyzer Sequencer (Applied Biosystems) in the Department of Zoology, University of Delhi, Delhi, India, with a MicroSeq Fullgene 16S rRNA gene sequencing kit. The 16S rRNA gene sequences of closely related strains were obtained using the sequence match program of the Ribosomal Database Project (RDP; http://rdp.cme. msu.edu/) and BLAST (http://www.ncbi.nlm.nih.gov).

A phylogenetic tree was constructed using $16 \mathrm{~S}$ rRNA gene sequences of strain Esp- $1^{\mathrm{T}}$ and the 12 most closely related species of the genus Pseudomonas with validly published names, along with an outgroup sequence. Multiple alignments of these 14 sequences were performed using CLUSTAL_X (Thompson et al., 1997), common gaps from all the selected sequences were removed and the alignment was checked manually for quality. Terminal nucleotides 


\section{Table 1. Differential phenotypic characteristics of strain Esp $-1^{\top}$ and related Pseudomonas species}

Strains: 1, P. panipatensis Esp-1 ${ }^{\mathrm{T}}$; 2, P. knackmussii DSM $6978^{\mathrm{T}} ; 3$, P. delhiensis MTCC $7601^{\mathrm{T}} ; 4$, P. citronellolis DSM 50332 $; 5$, P. jinjuensis DSM $16612^{\mathrm{T}} ; 6$, P. nitroreducens DSM $14399^{\mathrm{T}}$; 7, P. multiresinivorans ATCC $700690^{\mathrm{T}}$. All tests were performed under reproducible laboratory conditions. + , Positive; ++ , strong positive; $(+)$, weak positive; - , negative; ND, not done. All strains tested positive for: growth on MacConkey agar and allantoin; DNase, catalase and oxidase; assimilation of L-proline, $o$-cresol, allantoin, pyruvate and citrate; and acid formation from D-glucose. All strains tested negative for: lecithinase; assimilation of inositol, pyrocatechal, aniline and para-nitrophenol; and acid formation from L-serine, sucrose, adonitol, sorbose, Triton X-100, $\alpha$-naphthol, inositol, rhamnose, trehalose, propionate, sorbitol, acetate, pyridine, heptane, cystine, L-histidine, L-arabinose, glycerol and toluene. All data are from this study unless otherwise indicated.

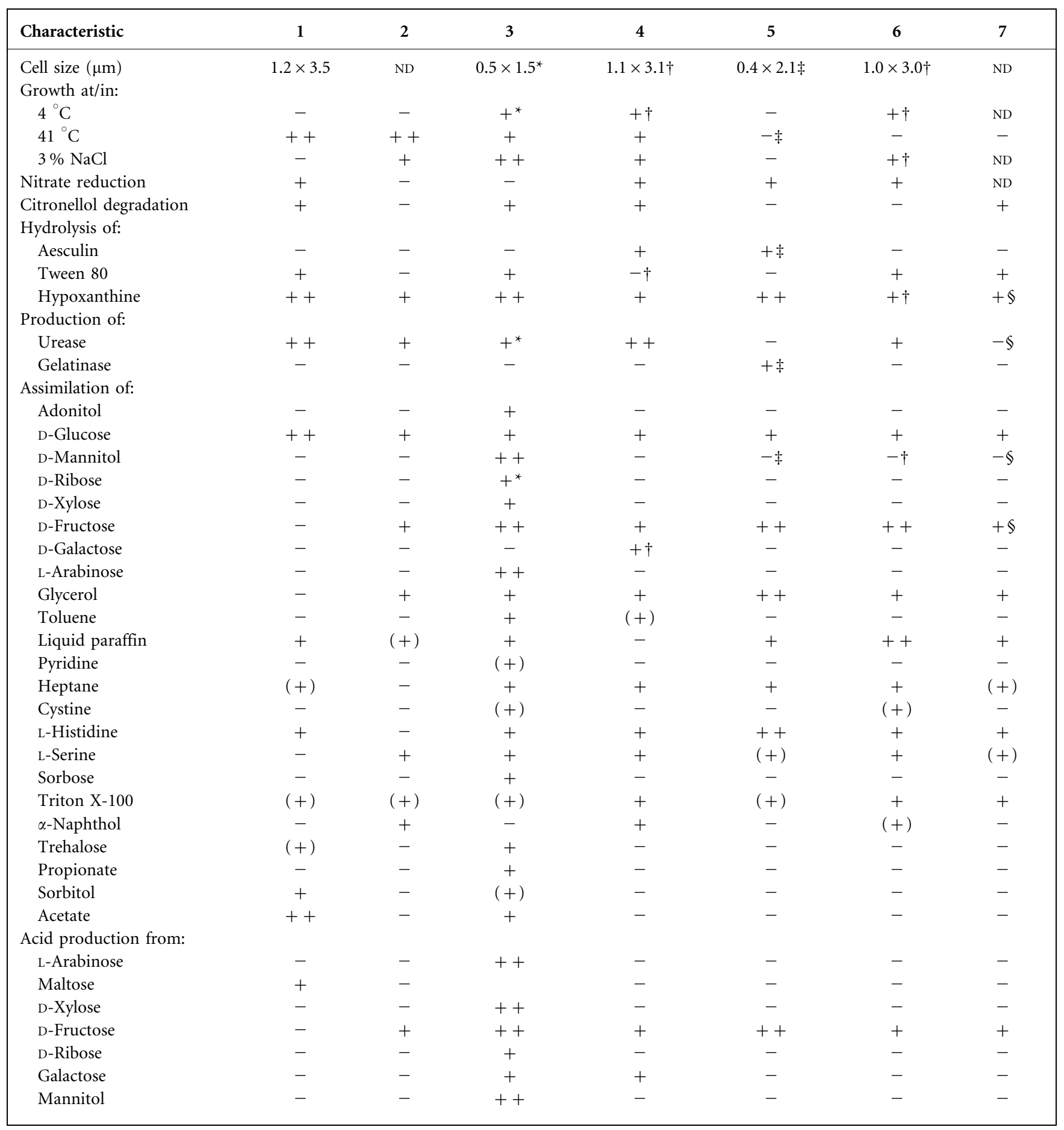

${ }^{\star}$ Prakash et al. (2007a).

$\dagger$ Palleroni (2005).

$\ddagger$ Kwon et al. (2003).

\$Mohn et al. (1999) and Lang et al. (2007). 
not common to all 14 sequences were removed. Phylogenetic trees were constructed by the neighbourjoining (Saitou \& Nei, 1987) and maximum-parsimony (Nei \& Kumar, 2000) methods using the MEGA3 package (Kumar et al., 2004). The evolutionary distance matrices for the neighbour-joining method were calculated using the Kimura two-parameter method (Kimura, 1980). Similarity values for the $16 \mathrm{~S}$ rRNA gene sequences were calculated using the FASTA program (Pearson \& Lipman, 1988).

The 16S rRNA gene sequence of strain Esp- $1^{\mathrm{T}}$ showed highest similarity to P. knackmussii DSM $6978^{\mathrm{T}}$ (98.9\%), followed by Pseudomonas multiresinivorans ATCC $700690^{\mathrm{T}}$ (98.9\%), Pseudomonas delhiensis MTCC $7601^{\mathrm{T}}(98.5 \%)$, Pseudomonas citronellolis DSM 50332 ${ }^{\mathrm{T}} \quad(98.7 \%)$, Pseudomonas nitroreducens DSM $14399^{\mathrm{T}}(98.5 \%)$ and Pseudomonas jinjuensis DSM $16612^{\mathrm{T}}(97.8 \%)$. The neighbour-joining tree indicated that strain Esp- $1^{\mathrm{T}}$ formed a cluster with these six strains (Fig. 2). A similar phylogenetic relationship was also obtained by the maximum-parsimony method (data not shown). 16S rRNA gene sequence similarities and phylogenetic analysis (with high bootstrap values) indicate that strain Esp- $1^{\mathrm{T}}$ is a member of the genus Pseudomonas that belongs to rDNA similarity group I (Palleroni, 1984) and the P. aeruginosa group of Anzai et al. (2000).

DNA-DNA hybridization of strain Esp- $1^{\mathrm{T}}$ was performed using the membrane filter method (Bala et al., 2004; Tourova \& Antonov, 1987) with the six most related strains based on 16S rRNA gene sequencing. DNA-DNA relatedness values of strain Esp- $1^{\mathrm{T}}$ with $P$. knackmussii DSM $6978^{\mathrm{T}}, P$. delhiensis MTCC $7601^{\mathrm{T}}, P$. jinjuensis DSM $16612^{\mathrm{T}}$, P. citronellolis DSM 50332 ${ }^{\mathrm{T}}$, P. multiresinivorans ATCC $700690^{\mathrm{T}}$ and $P$. nitroreducens DSM $14399^{\mathrm{T}}$ were $32.9,30.2,20.6,23.4,23.4$ and $20 \%$, respectively. Percentage relatedness calculated on the basis of the data obtained (mean of four replicates) by DNA-DNA hybridization (summarized in Supplementary Table S1, available in IJSEM Online) showed less than $70 \%$ relatedness, which is within the threshold value for bacterial species delineation (Wayne et al., 1987). These data further indicate that strain Esp- $1^{\mathrm{T}}$ represents a novel species of the genus Pseudomonas.

Strain Esp- $1^{\mathrm{T}}$ contained $\mathrm{C}_{10: 0} \quad 3-\mathrm{OH} \quad(0.99 \%), \mathrm{C}_{12: 0}$ (2.13\%), $\mathrm{C}_{12: 0}$ 2-OH (5.30\%), $\mathrm{C}_{12: 0} \quad 3-\mathrm{OH}(4.49 \%)$, $\mathrm{C}_{14: 0}(2.62 \%), \mathrm{C}_{16: 0}(32.27 \%), \mathrm{C}_{17: 0}$ cyclo (12.41\%), $\mathrm{C}_{18: 1} \omega 7 c(15.29 \%), \mathrm{C}_{18: 0}(3.37 \%), \mathrm{C}_{19: 0}$ cyclo $\omega 8 c$ $(8.04 \%)$ and summed feature $3\left(\mathrm{C}_{16: 1} \omega 7 c\right.$ and/or $\mathrm{C}_{15: 0}$ $2-\mathrm{OH}$ iso; $11.12 \%)$. Fatty acid analysis revealed that $\mathrm{C}_{16: 0}$ and $\mathrm{C}_{18: 1} \omega 7 c$ were the dominant fatty acids in the cell wall of strain Esp- $1^{\mathrm{T}}$. The fatty acid profile of strain Esp- $1^{\mathrm{T}}$ was compared with those of the type strains of some Pseudomonas species. The presence of high levels of $\mathrm{C}_{18: 1} \omega 7 c$ and $\mathrm{C}_{16: 0}$, along with $\mathrm{C}_{10: 0} 3-\mathrm{OH}, \mathrm{C}_{12: 0} 2-\mathrm{OH}$ and $\mathrm{C}_{12: 0} \quad 3-\mathrm{OH}$ (Table 2) in the fatty acid profiles corresponds with the profiles of other members of the genus Pseudomonas.

The position of strain Esp- $1^{\mathrm{T}}$ in the genus Pseudomonas is indicated by its distinctive phenotypic features, 16S rRNA gene sequence and chemotaxonomic features. Sufficient divergence from other species is emphasized by its phenotypic features, such as degradation of citronellol, urease production, hydrolysis of Tween 80, growth at different $\mathrm{NaCl}$ concentrations, nitrate reduction, and acid production from and assimilation of different substrates (Table 1), as well as low DNA-DNA hybridization values. Thus, it is concluded that strain Esp $-1^{\mathrm{T}}$ represents a novel species of Pseudomonas for which the name Pseudomonas panipatensis sp. nov. is proposed.

\section{Description of Pseudomonas panipatensis sp. nov.}

Pseudomonas panipatensis (pa.ni.pa.ten'sis. N.L. fem adj. panipatensis pertaining to Panipat, the place of isolation of the bacterium).

Cells are Gram-negative, aerobic, non-sporulating, motile rods $(1.0-1.2 \times 2.8-3.5 \mu \mathrm{m})$. Possesses a single polar flagellum. Colonies are smooth, circular and muddy-white, growing up to $1.5 \mathrm{~mm}$ diameter on LB agar after $72 \mathrm{~h}$ incubation at $30{ }^{\circ} \mathrm{C}$. Grows well at $28-37{ }^{\circ} \mathrm{C}$ and $\mathrm{pH} 5-9$, but growth does not occur in the presence of $3 \% \mathrm{NaCl}$.

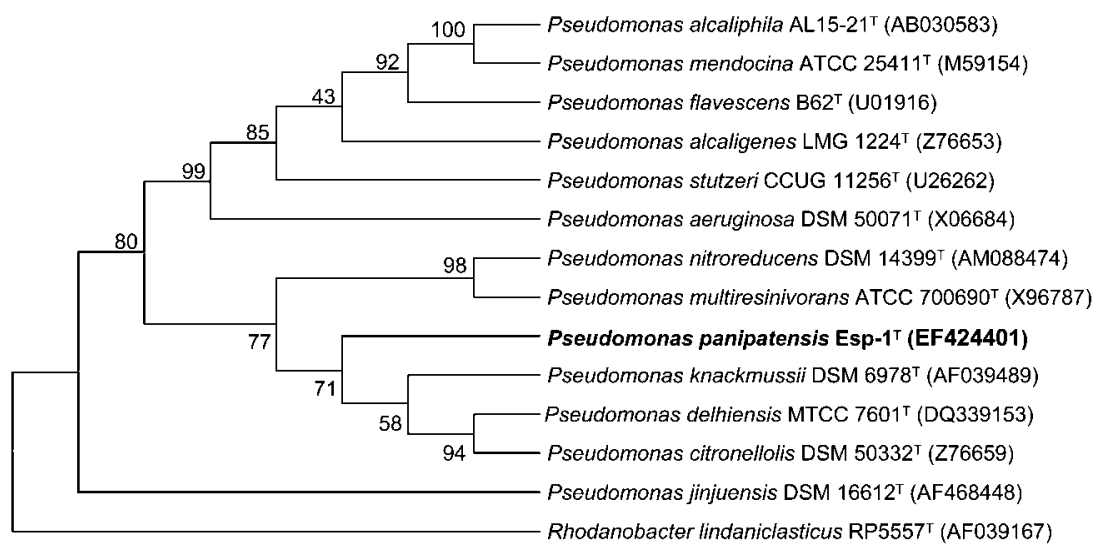

Fig. 2. Neighbour-joining phylogenetic tree based on 16S rRNA gene sequences showing the relationship of strain Esp- $1^{\top}$ with other related taxa. The tree was rooted by using Rhodanobacter lindanoclasticus RP5557 ${ }^{\top}$ as outgroup. Numbers at branches indicate bootstrap values of 100 resamplings. 
Table 2. Cellular fatty acid compositions (\%) of strain Esp- $1^{\top}$ and the type strains of related Pseudomonas species

Strains: 1, P. panipatensis Esp- $1^{\mathrm{T}}$; 2, P. knackmussii DSM 6978 ${ }^{\mathrm{T}}$ (Stolz et al., 2007); 3, P. delhiensis MTCC $7601^{\mathrm{T}}$ (Prakash et al., 2007a); 4, P. citronellolis DSM 50332 ${ }^{\mathrm{T}}$ (Prakash et al., 2007a); 5, P. nitroreducens DSM 14399 ${ }^{\mathrm{T}}$ (Prakash et al., 2007a); 6, P. jinjuensis DSM 16612 ${ }^{\mathrm{T}}$ (Prakash et al., 2007a); 7. P. multiresinivorans ATCC $700690^{\mathrm{T}}$ (Lang et al., 2007). All strains were grown on trypticase soy agar at $28{ }^{\circ} \mathrm{C}$ for $48 \mathrm{~h}$ prior to fatty acid analysis. Empty cells indicate that fatty acids were not detected.

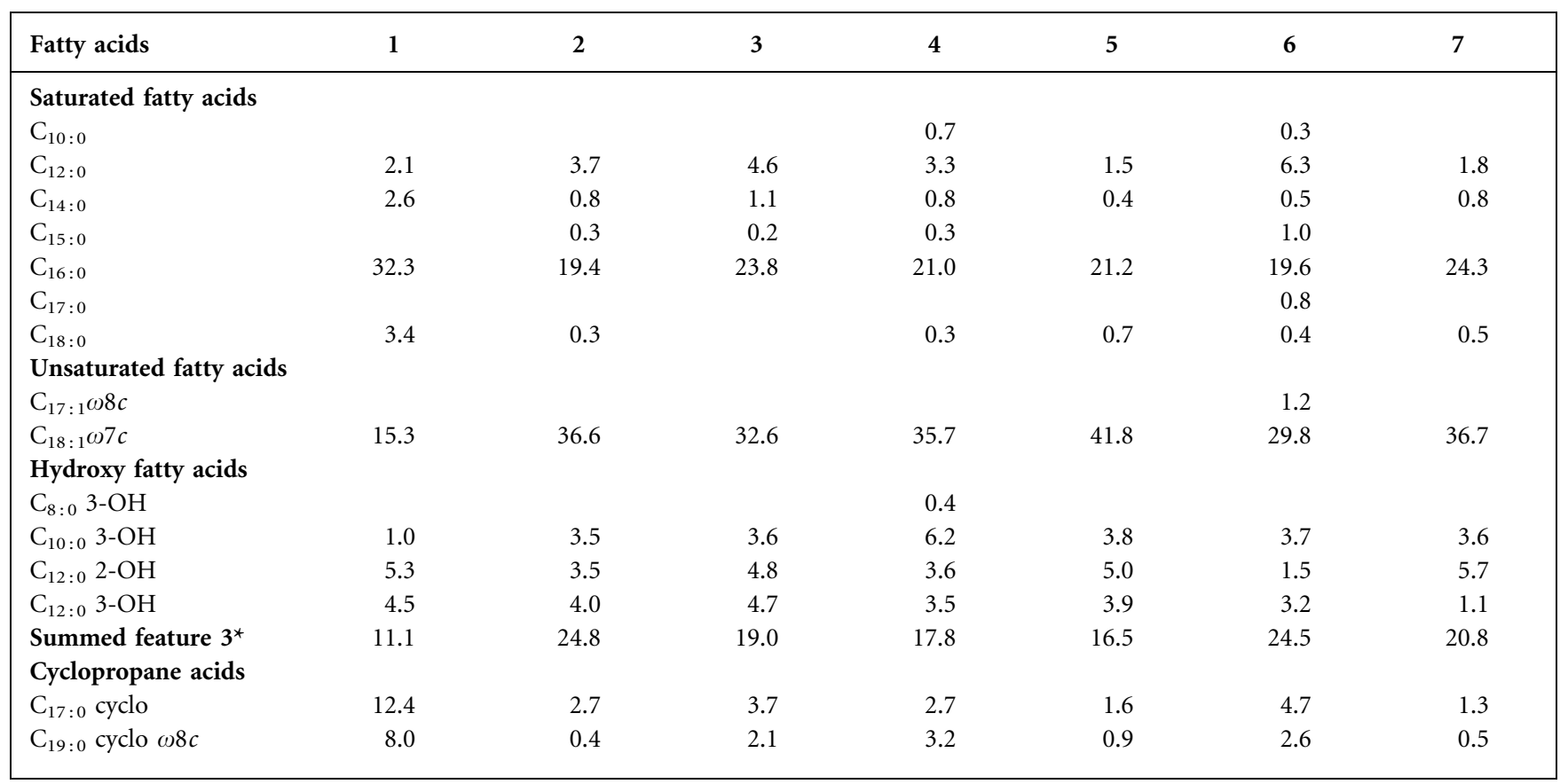

${ }^{\star}$ Summed features represent groups of two or three fatty acids that can not be separated by GLC with the MIDI system. Summed feature 3 contains one or more of the fatty acids $\mathrm{C}_{16: 1} \omega 7 c$ and $\mathrm{C}_{15: 0}$ iso $2-\mathrm{OH}$.

Positive for oxidase, catalase, DNase, nitrate reductase and urease, but negative for indole, methyl red/VogesProskauer, gelatinase and amylase. D-Glucose, D-fructose, D-galactose and D-arabinose are utilized as carbon sources, but not egg yolk, D-xylose, lactose or raffinose. Growth is observed on MacConkey agar. Acid is produced from Dglucose and maltose, but not from adonitol, mannitol, ribose, D-fructose, D-galactose, D-arabinose, sucrose, xylose, raffinose or lactose. The fatty acid profile contains $\mathrm{C}_{10: 0} \quad 3-\mathrm{OH} \quad(0.99 \%), \mathrm{C}_{12: 0} \quad(2.13 \%), \mathrm{C}_{12: 0} \quad 2-\mathrm{OH}$ $(5.30 \%), \mathrm{C}_{12: 0} 3-\mathrm{OH}(4.49 \%), \mathrm{C}_{14: 0}(2.62 \%), \mathrm{C}_{16: 0}$ (32.27\%), $\mathrm{C}_{17: 0}$ cyclo (12.41\%), $\mathrm{C}_{18: 1} \omega 7 \mathrm{c}(15.29 \%)$, $\mathrm{C}_{18: 0}(3.37 \%), \mathrm{C}_{19: 0}$ cyclo $\omega 8 c(8.04 \%)$ and summed feature $3\left(\mathrm{C}_{16: 1} \omega 7 c\right.$ and/or $\mathrm{C}_{15: 0} 2-\mathrm{OH}$ iso; $\left.11.12 \%\right)$. Table 1 summarizes other phenotypic properties.

The type strain is Esp $-1^{\mathrm{T}}\left(=\right.$ MTCC $\left.8990^{\mathrm{T}}=\mathrm{CCM} 7469^{\mathrm{T}}\right)$, isolated from oil-contaminated soil of Panipat Oil Refinery, India.

\section{Acknowledgements}

The study was supported by National Bureau of Agriculturally Important Microorganisms (NBAIM), Indian Council of Agricultural Research (ICAR), Government of India. We would like to thank J. P.
Euzèby for etymological advice and Hans-Jürgen Busse for providing Pseudomonas knackmussii DSM $6978^{\mathrm{T}}$.

\section{References}

Anzai, Y., Kim, H., Park, J.-Y., Wakabayashi, H. \& Oyaizu, H. (2000). Phylogenetic affiliation of the pseudomonads based on 16S rRNA sequence. Int J Syst Evol Microbiol 50, 1563-1589.

Bala, S., Khanna, R., Dadhwal, M., Prabagaran, S. R., Shivaji, S., Cullum, J. \& Lal, R. (2004). Reclassification of Amycolatopsis mediterranei DSM 46095 as Amycolatopsis rifamycinica sp. nov. Int J Syst Evol Microbiol 54, 1145-1149.

Bhattacharya, D., Sarma, P. M., Krishnan, S., Mishra, S. \& Lal, B. (2003). Evaluation of genetic diversity among Pseudomonas citronellolis strains isolated from oily sludge-contaminated sites. Appl Environ Microbiol 69, 1435-1441.

Collins, C. H., Lyne, P. M. \& Grange, J. M. (1989). Microbiological Methods, 6th edn. London: Butterworth.

Elkin, S. \& Geddes, D. (2003). Pseudomonal infection in cystic fibrosis: the battle continues. Expert Rev Anti Infect Ther 1, 609-618.

Farmer, J. J., III (1999). Enterobacteriaceae: introduction and identification. In Manual of Clinical Microbiology, 7th edn, pp. 442458. Edited by P. R. Murray, E. J. Baron, M. A. Pfaller, F. C. Tenover \& R. H. Yolken. Washington, DC: American Society for Microbiology. 
Gordon, R. E., Barnett, D. A., Handerhan, J. E. \& Pang, C. H.-N. (1974). Nocardia coeliaca, Nocardia autotrophica, and the nocardin strain. Int J Syst Bacteriol 24, 54-63.

Johnsen, K., Andersen, S. \& Jacobsen, C. S. (1996). Phenotypic and genotypic characterization of phenanthrene-degrading fluorescent Pseudomonas biovars. Appl Environ Microbiol 62, 3818-3825.

Kersters, K., Ludwig, W., Vancanneyt, M., De Vos, P., Gillis, M. \& Schleifer, K. H. (1996). Recent changes in the classification of the pseudomonads: an overview. Syst Appl Microbiol 19, 465-477.

Kimura, M. (1980). A simple method for estimating evolutionary rates of base substitutions through comparative studies of nucleotide sequences. J Mol Evol 16, 111-120.

Kiyohara, H., Nagao, K. \& Yana, K. (1982). Rapid screen for bacteria degrading water-insoluble, solid hydrocarbons on agar plates. Appl Environ Microbiol 43, 454-457.

Kiyohara, H., Takizawa, N. \& Nagao, K. (1992). Natural distribution of bacteria metabolizing many kinds of polycyclic aromatic hydrocarbons. J Ferment Bioeng 74, 49-51.

Kumar, S., Tamura, K. \& Nei, M. (2004). MEGA3: integrated software for Molecular Evolutionary Genetics Analysis and sequence alignment. Brief Bioinform 5, 150-163.

Kuykendall, L. D., Roy, M. A., O'Neill, J. J. \& Devine, T. E. (1988). Fatty acids, antibiotic resistance, and deoxyribonucleic acid homology groups of Bradyrhizobium japonicum. Int J Syst Bacteriol 38, 358-361.

Kwon, S. W., Kim, J. S., Park, I. C., Yoon, S. H., Park, D. H., Lim, C. K. \& Go, S. J. (2003). Pseudomonas koreensis sp. nov., Pseudomonas umsongensis sp. nov. and Pseudomonas jinjuensis sp. nov., novel species from farm soils in Korea. Int J Syst Evol Microbiol 53, $21-27$.

Lal, B. \& Khanna, S. (1996). Degradation of crude oil by Acinetobacter calcoaceticus and Alcaligenes odorans. J Appl Bacteriol 81, 355-362.

Lang, E., Griese, B., Spröer, C., Schumann, P., Steffen, M. \& Verbarg, S. (2007). Characterization of 'Pseudomonas azelaica' DSM 9128, leading to emended descriptions of Pseudomonas citronellolis Seubert 1960 (Approved Lists 1980) and Pseudomonas nitroreducens Iizuka and Komagata 1964 (Approved Lists 1980), including Pseudomonas multiresinivorans as its later heterotypic synonym. Int J Syst Evol Microbiol 57, 878-882.

Levitski-Heikkila, T. V. \& Ullian, M. E. (2005). Peritonitis with multiple rare environmental bacteria in a patient receiving long-term peritoneal dialysis. Am J Kidney Dis 46, e119-e124.

López-Romalde, S., Magariños, B., Ravelo, C., Toranzo, A. E. \& Romalde, J. L. (2003). Existence of two O-serotypes in the fish pathogen Pseudomonas anguilliseptica. Vet Microbiol 94, 325-333.

Miller, L. T. (1982). Single derivatization method for routine analysis of bacterial whole-cell fatty acid methyl esters, including hydroxy acids. J Clin Microbiol 16, 584-586.

Mishra, S., Lal, B., Jyot, J., Rajan, S. \& Khanna, S. (1999). Field study: in situ bioremediation of oily sludge contaminated land using oilzapper. In Proceedings of Hazardous and Industrial Wastes, pp. 177-186. Edited by D Bishop. Pennsylvania, USA: Technomic Publishing Co.

Mishra, S., Jyot, J., Kuhad, R. C. \& Lal, B. (2001). In situ bioremediation potential of an oily sludge-degrading bacterial consortium. Curr Microbiol 43, 328-335.

Mohn, W. W., Wilson, A. E., Bicho, P. \& Moore, E. R. B. (1999). Physiological and phylogenetic diversity of bacteria growing on resin acids. Syst Appl Microbiol 22, 68-78.

Nei, M. \& Kumar, S. (2000). Molecular Evolution and Phylogenetics. New York: Oxford University Press.
O’Mahony, M. M., Dobson, A. D., Barnes, J. D. \& Singleton, I. (2006). The use of ozone in the remediation of polycyclic aromatic hydrocarbon contaminated soil. Chemosphere 63, 307-314.

Onaca, C., Kieninger, M., Engesser, K.-H. \& Altenbuchner, J. (2007). Degradation of alkyl methyl ketones by Pseudomonas veronii MEK700. J Bacteriol 189, 3759-3767.

Oyaizu, H. \& Komagata, K. (1983). Grouping of Pseudomonas species on the basis of cellular fatty acid composition and the quinone system with special reference to the existence of 3-hydroxy fatty acids. J Gen Appl Microbiol 29, 17-40.

Pal, R., Bala, S., Dadhwal, M., Kumar, M., Dhingra, G., Prakash, O., Prabagaran, S. R., Shivaji, S., Cullum, J. \& other authors (2005). Hexachlorocyclohexane-degrading bacterial strains Sphingomonas paucimobilis B90A, UT26 and $\mathrm{Sp}+$, having similar lin genes, represent three distinct species, Sphingobium indicum sp. nov., Sphingobium japonicum sp. nov. and Sphingobium francense sp. nov., and reclassification of [Sphingomonas] chungbukensis as Sphingobium chungbukense comb. nov. Int J Syst Evol Microbiol 55, 1965-1972.

Palleroni, N. J. (1984). Genus I. Pseudomonas Migula 1894, 237. In Bergey's Manual of Systematic Bacteriology, vol. 1, pp. 141-199. Edited by N. R. Krieg \& J. G. Holt. Baltimore: Williams \& Wilkins.

Palleroni, N. J. (1993). Pseudomonas classification. A new case history in the taxonomy of Gram-negative bacteria. Antonie Van Leeuwenhoek 64, 231-251.

Palleroni, N. J. (2005). Genus I. Pseudomonas Migula 1894, $237^{\mathrm{AL}}$. In Bergey's Manual of Systematic Bacteriology, 2nd edn, vol. 2, The Proteobacteria, Part B The Gammaproteobacteria, pp. 323-379. Edited by D. J. Brenner, N. R. Krieg \& J. T. Staley. New York: Springer.

Pearson, W. R. \& Lipman, D. J. (1988). Improved tools for biological sequence comparison. Proc Natl Acad Sci U S A 85, 2444-2448.

Prakash, O., Kumari, K. \& Lal, R. (2007a). Pseudomonas delhiensis sp. nov., from a fly ash dumping site of a thermal power plant. Int J Syst Evol Microbiol 57, 527-531.

Prakash, O., Verma, M., Sharma, P., Kumar, M., Kumari, K., Singh, A., Kumari, H., Jit, S., Gupta, S. K., Khanna, M. \& Lal, R. (2007b). Polyphasic approach of bacterial classification - an overview of recent advances. Indian J Microbiol 47, 98-108.

Saitou, N. \& Nei, M. (1987). The neighbor-joining method: a new method for reconstructing phylogenetic trees. Mol Biol Evol 4, 406-425.

Sneath, P. H. A., Stevens, M. \& Sackin, M. J. (1981). Numerical taxonomy of Pseudomonas based on published record of substrate utilization. Antonie van Leeuwenhoek 47, 423-448.

Stackebrandt, E., Frederiksen, W., Garrity, G. M., Grimont, P. A. D., Kämpfer, P., Maiden, M. C. J., Nesme, X., Rosselló-Mora, R., Swings, J. \& other authors (2002). Report of the ad hoc committee for the reevaluation of the species definition in bacteriology. Int J Syst Evol Microbiol 52, 1043-1047.

Stanier, R. Y., Palleroni, N. J. \& Doudoroff, M. (1966). The aerobic pseudomonads: a taxonomic study. J Gen Microbiol 43, 159-271.

Stolz, A., Busse, H.-J. \& Kampfer, P. (2007). Pseudomonas knackmussii sp. nov. Int J Syst Evol Microbiol 57, 572-576.

Thompson, J. D., Gibson, T. J., Plewniak, F., Jeanmougin, F. \& Higgins, D. G. (1997). The CLUSTAL_X windows interface: flexible strategies for multiple sequence alignment aided by quality analysis tools. Nucleic Acids Res 25, 4876-4882.

Tourova, T. P. \& Antonov, A. S. (1987). Identification of microorganisms by rapid DNA-DNA hybridization. Methods Microbiol 19, 333-355. 
Vancanneyt, M., Witt, S., Abraham, W.-R., Kersters, K. \& Fredrickson, H. L. (1996). Fatty acid content in whole-cell hydrolysates and phospholipid fractions of pseudomonads: a taxonomic evaluation. Syst Appl Microbiol 19, 528-540.

Wayne, L. G., Brenner, D. J., Colwell, R. R., Grimont, P. A. D., Kandler, O., Krichevsky, M. I., Moore, L. H., Moore, W. E. C., Murray, R. G. E.

\& other authors (1987). International Committee on Systematic
Bacteriology. Report of the ad hoc committee on reconciliation of approaches to bacterial systematics. Int J Syst Evol Microbiol 37, 463-464.

Whyte, L. G., Goalen, B., Hawari, J., Labbé, D., Greer, C. W. \& Nahir, M. (2001). Bioremediation treatability assessment of hydrocarboncontaminated soils from Eureka, Nunavut. Cold Regions Sci Technol 32, 121-132. 